Article

\title{
Analysis of the TP53 Deleterious Single Nucleotide Polymorphisms Impact on Estrogen Receptor Alpha-p53 Interaction: A Machine Learning Approach
}

\author{
Kumaraswamy Naidu Chitrala ${ }^{1,2}$, Mitzi Nagarkatti ${ }^{2}$, Prakash Nagarkatti ${ }^{2}$ and \\ Suneetha Yeguvapalli ${ }^{1}$ ** \\ 1 Department of Zoology, Sri Venkateswara University, Tirupati 517502, India; cksnaidu@gmail.com \\ 2 Department of Pathology, Microbiology and Immunology, University of South Carolina School of Medicine, \\ Columbia, SC 29208, USA; Mitzi.Nagarkatti@uscmed.sc.edu (M.N.); prakash@mailbox.sc.edu (P.N.) \\ * Correspondence: ysuneethareddy4@gmail.com
}

Received: 8 April 2019; Accepted: 22 May 2019; Published: 18 June 2019

\begin{abstract}
Breast cancer is a leading cancer type and one of the major health issues faced by women around the world. Some of its major risk factors include body mass index, hormone replacement therapy, family history and germline mutations. Of these risk factors, estrogen levels play a crucial role. Among the estrogen receptors, estrogen receptor alpha $(E R \alpha)$ is known to interact with tumor suppressor protein p53 directly thereby repressing its function. Previously, we have studied the impact of deleterious breast cancer-associated non-synonymous single nucleotide polymorphisms (nsnps) rs11540654 (R110P), rs17849781 (P278A) and rs28934874 (P151T) in TP53 gene on the p53 DNA-binding core domain. In the present study, we aimed to analyze the impact of these mutations on p53-ER $\alpha$ interaction. To this end, we, have modelled the full-length structure of human p53 and validated its quality using PROCHECK and subjected it to energy minimization using NOMAD-Ref web server. Three-dimensional structure of ER $\alpha$ activation function-2 (AF-2) domain was downloaded from the protein data bank. Interactions between the modelled native and mutant (R110P, P278A, P151T) p53 with ER $\alpha$ was studied using ZDOCK. Machine learning predictions on the interactions were performed using Weka software. Results from the protein-protein docking showed that the atoms, residues and solvent accessibility surface area (SASA) at the interface was increased in both p53 and ER $\alpha$ for R110P mutation compared to the native complexes indicating that the mutation R110P has more impact on the p53-ER $\alpha$ interaction compared to the other two mutants. Mutations $\mathrm{P} 151 \mathrm{~T}$ and P278A, on the other hand, showed a large deviation from the native p53-ER $\alpha$ complex in atoms and residues at the surface. Further, results from artificial neural network analysis showed that these structural features are important for predicting the impact of these three mutations on p53-ER $\alpha$ interaction. Overall, these three mutations showed a large deviation in total SASA in both p53 and $\mathrm{ER} \alpha$. In conclusion, results from our study will be crucial in making the decisions for hormone-based therapies against breast cancer.
\end{abstract}

Keywords: breast cancer; TP53; ER $\alpha$; single nucleotide polymorphism; genetic factors; machine learning

\section{Introduction}

Breast cancer is one of the leading causes of cancer deaths faced by women around the world today and is a major health issue faced in the western part of the world. The burden of breast cancer is not evenly distributed showing a large variation in the incidence, mortality and survival between different countries and regions and within specific regions [1]. Recent reports showed an increase 
in the incidence of breast cancer in low and middle-income countries with an approximately $45 \%$ of new cases being diagnosed each year and more than $55 \%$ of deaths being occurred in low and middle-income countries [2-4]. In Asian countries like India, its prevalence is increasing slowly with an increasing incidence rising from $0.5-2 \%$ across all regions of India and in all age groups with an average age group found to be 35 years of age [5].

Alcohol intake, body mass index, hormone replacement therapy with estrogen and progesterone, radiation exposure, early menarche, late menopause, age at first childbirth, current age, past history of breast cancer, family history and germline mutations are some of the non-genetic factors that confer risk to breast cancer [6]. Among these risk factors, prolonged exposure to sex steroid estrogen (early menarche, late menopause, or postmenopausal hormone replacement therapy) is associated with a high breast cancer risk [7]. Estrogen is a female hormone secreted mainly by the ovaries to proliferate the endometrium as a part of the menstrual cycle. Functions of estrogen include the promotion of subcutaneous fat accumulation, mammary gland proliferation, water and sodium retention and calcium deposition [8]. Before menopause, it stimulates the vaginal epithelial cells to produce large amounts of glycogen and after menopause, its decreased levels cause lowering of glycogen content [9]. Estrogen ablation or anti-estrogen strategy is an effective means of prevention or treatment of breast cancer, especially in estrogen receptors (ERs)-dependent breast cancer.

Estrogen exerts its effects through two types of specific receptors i.e., estrogen receptor alpha $(E R \alpha)$ and estrogen receptor beta $(E R \beta)$. Both $E R \alpha$ and $E R \beta$ are ligand-dependent transcription factors mediating the biological effects of estrogens and antiestrogens [10]. Both ER $\alpha$ and ER $\beta$ are the members of a superfamily of genes that contain nuclear receptors for diverse hydrophobic ligands such as steroid hormones (estrogens, progestins, glucocorticoids, mineralocorticoids), retinoic acids (vitamin A), vitamin D, prostaglandins, and thyroid hormones [11]. Among ER $\alpha$ and ER $\beta$, the clinical role of ER $\alpha$ has only been established and it plays a prominent role in the etiology of breast cancer and with respect to the prognosis of breast cancer, it has been extensively studied.

An in vitro study on $E R \alpha$ showed that, though $E R \alpha$ associate with the chemoresistance of breast cancer, ER $\alpha$ itself does not mediate this resistance process [12]. It prevents p53-dependent apoptosis in breast cancer [13] and is known to interact with the other receptors like Retinoic acid receptor $\alpha$ which is a known estrogen target gene in breast cancer cells [14]. ER $\alpha$ interacts with tumor suppressor protein p53 directly and represses its function thereby promoting the proliferation of breast cancer cells [15]. However, it is known that the physical interaction between p53 and ER $\alpha$ interferes with each other's activities to regulate gene expression [16]. Histone deacetylase 1 binds to p53 and down-regulates its transactivation function, which is largely dependent on the $30 \mathrm{C}$-terminal residues of $\mathrm{p} 53$. The same region of $\mathrm{p} 53$ is known to be the domain that interacts with ER $\alpha$ [17]. Binding of ER $\alpha$ with $p 53$ leads to the repressing of its functions in breast cancer cells, indicating that inhibition of p53 functions by ER $\alpha$ contributes to the inactivation of p53 [18].

The ER $\alpha$ consists of 595 amino acids with a molecular weight of $66 \mathrm{kDa}$ separated into six different functional domains (A-F) [19]. Among them, the activation function-2 (AF-2) domain of ER $\alpha$ and the C-terminal regulatory domain of p53 are necessary for the interaction [15]. The respective interaction of ER $\alpha$ with p53 is shown in Figure 1 given below. Here, in the present study we analyzed the impact of p53 DNA binding domain deleterious breast cancer-associated nSNPs predicted in our previous study [20] on the p53-ER $\alpha$ interaction. 
DNA Binding domain

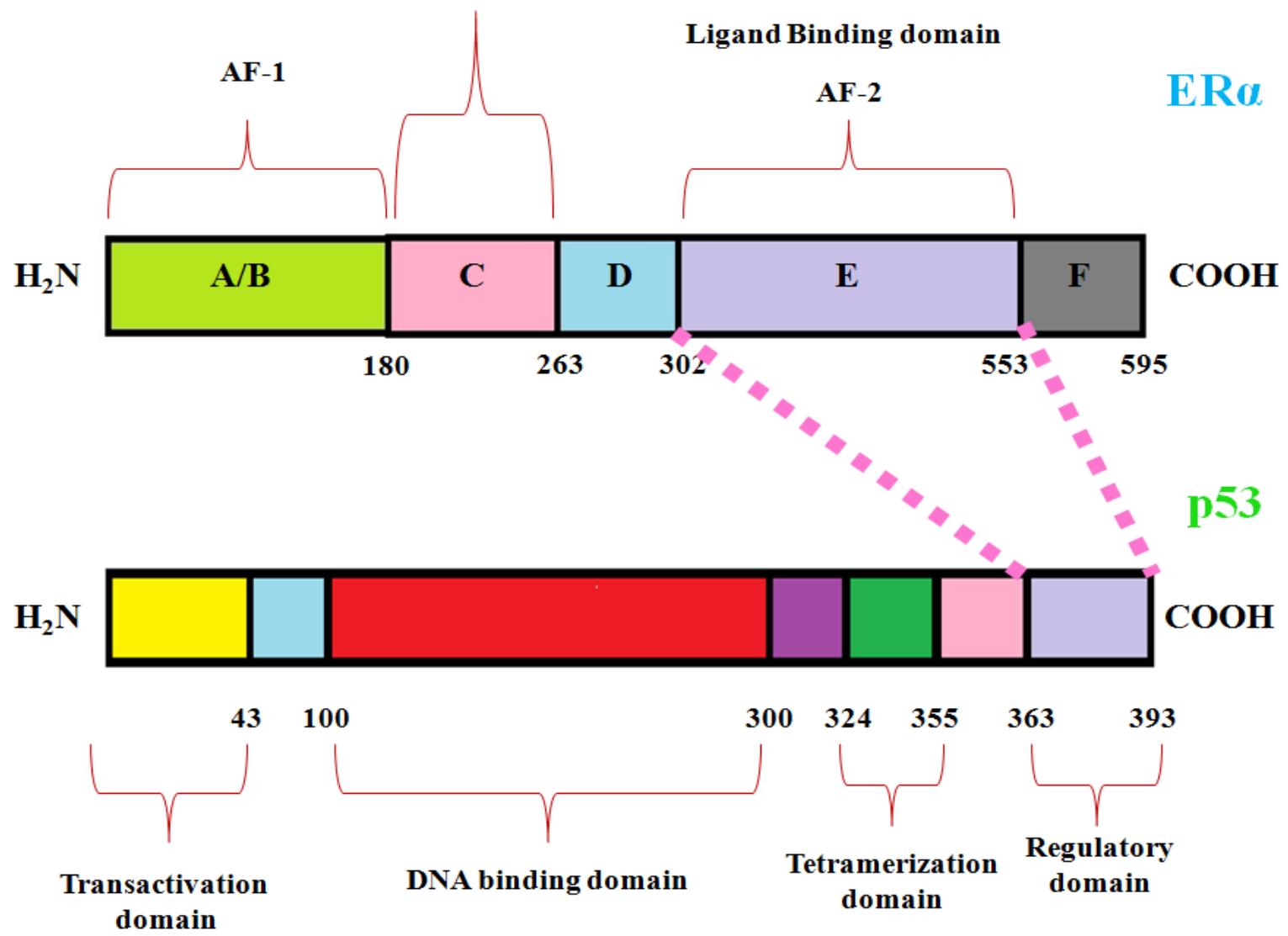

Figure 1. Schematic representation of interaction between ER $\alpha$ and p53. Region important for ER $\alpha-\mathrm{p} 53$ interaction is shown in pink colour dotted lines. ER $\alpha$ domain regions were shown in the top and p53 domain regions were shown at the bottom. AF1 refers to constitutive transcription activation 1 domain and AF2 refers to the transcription-activating function 2.

\section{Results}

\subsection{Modeling the p53 Full-Length Protein Structure}

A BLAST search for respective domains of p53 showed several hits. Among them, the one with the highest similarity was considered for modelling. Respective templates used for the domains in p53 were shown in Table 1 given below. Among several 3D models generated using homology modelling, the best model was selected after a series of refining and minimization. The three-dimensional structure of the generated model is shown in Figure 2 given below. Ramachandran plot drawn through the PROCHECK program validated the model with $90.1 \%$ of the total residues in the most favored regions and $9.9 \%$ in the additional allowed regions. None of the residues were located in the disallowed region confirming that the protein backbone dihedral angles phi $(\Phi)$ and psi $(\Psi)$ occupied reasonably accurate positions in the selected 3D model.

Table 1. List of templates used for modelling p53 structure.

\begin{tabular}{cc}
\hline Domain Name & PDB ID: Chain Name \\
\hline Transactivation domain & 2LY4:B, 2GS0:B \\
\hline DNA binding domain & 2OCJ:A,1TSR:A \\
\hline Tetramerization domain & 1OLG:A, 1C26:A \\
\hline Regulatory domain & 1DT7:X, 2H4J:D, 1JSP:A \\
\hline
\end{tabular}




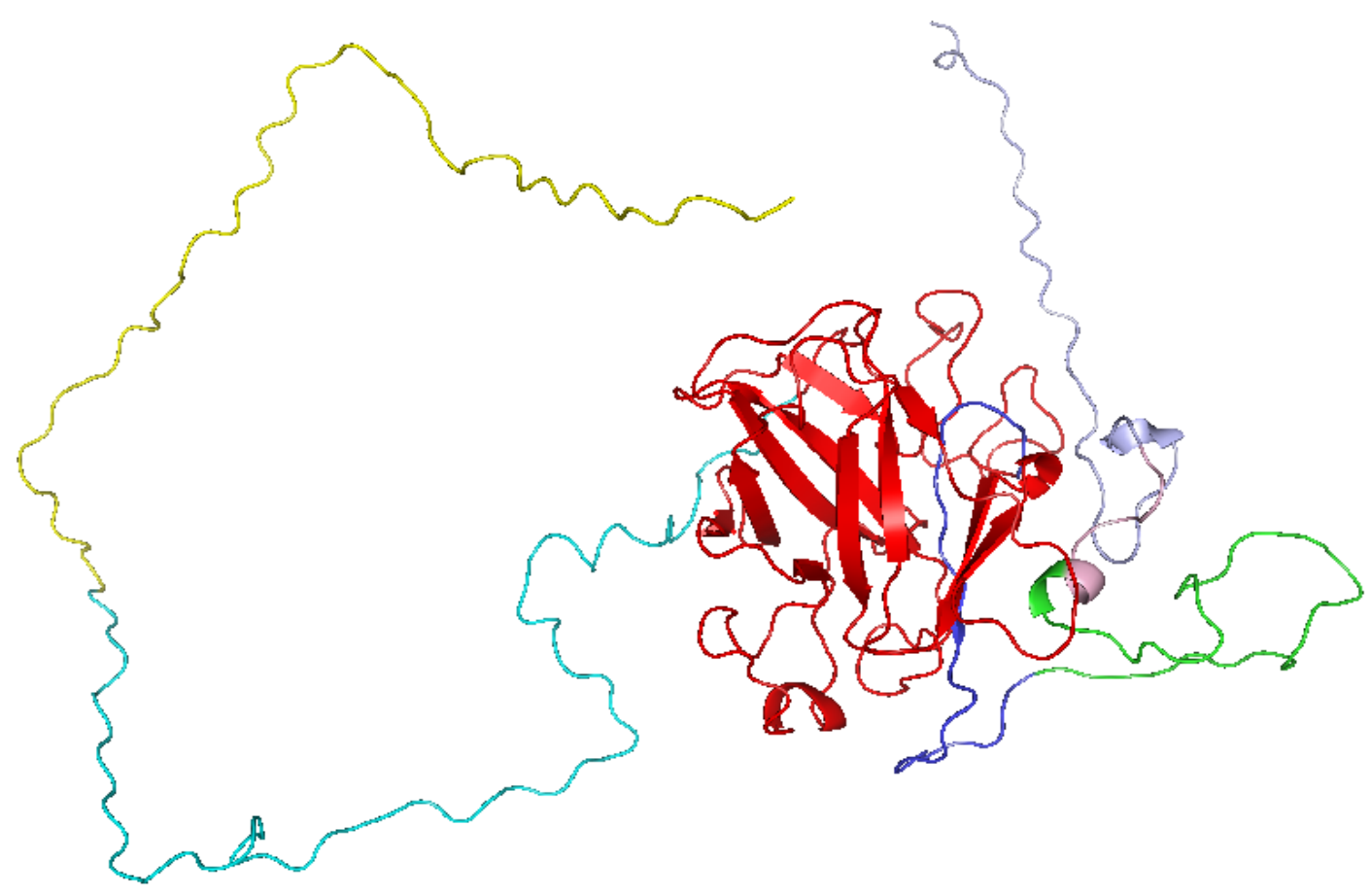

Figure 2. Three-dimensional structure of full length $\mathrm{p} 53$ structure. Transactivation domain is represented in yellow, DNA binding domain is shown in red, tetramerization domain is shown in green and regulatory domain is shown in light blue color.

\subsection{Impact of $p 53$ Mutants on $p 53-E R \alpha$ Interaction}

Protein-protein docking between $\mathrm{p} 53$ and ER $\alpha$ from ZDOCK analysis resulted in ten complexes each for native, R110P, P151T and P278A. The average of the properties of these complexes showed that interface atoms, interface residues and interface SASA was increased in both p53 and ER $\alpha$ for R110P compared to the native complexes indicating that R110P have more impact on the p53-ER $\alpha$ interaction on the interface compared to the other mutants. P151T and P278A, on the other hand, showed a large deviation from the native p53-ER $\alpha$ complex in the surface atoms and surface residues. Overall, all three mutants showed a large deviation in the total solvent accessible surface area in both p53 and ER $\alpha$ (Figure 3). Analysis of the number of hydrogen bonding residues and the number of salt bridges showed that an increase in the number of hydrogen bonding residues was shown by $\mathrm{R} 110 \mathrm{P}$ compared to native complex whereas an increase in number salt bridge forming residues were showed by P278A (Figure 4). Analysis of structure solvent energy and the average gain in the complex formation properties showed all the three mutants deviating from the native indicating that all these three mutants have an impact on the p53-ER $\alpha$ interaction (Figure 5). Overall, these results indicate that all these three mutants have an impact on the p53-ER $\alpha$ interaction. 

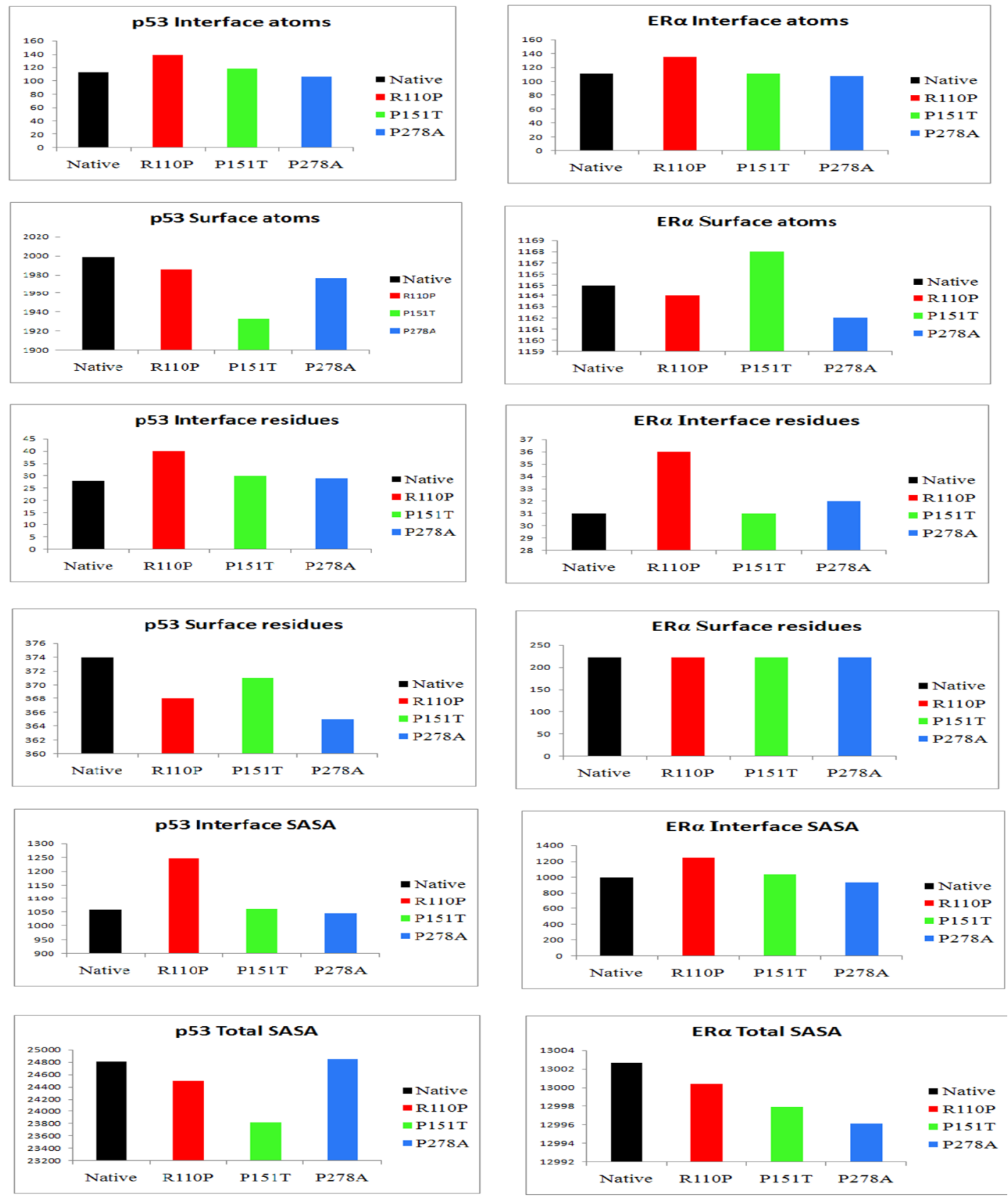

Figure 3. Surface, interface and solvent accessible surface analysis of the impact of three mutants R110P, P151T and P278A on the p53-ER $\alpha$ interaction. Black: native or WT, Red: R110P, Green: P151T, Blue: P278A. 

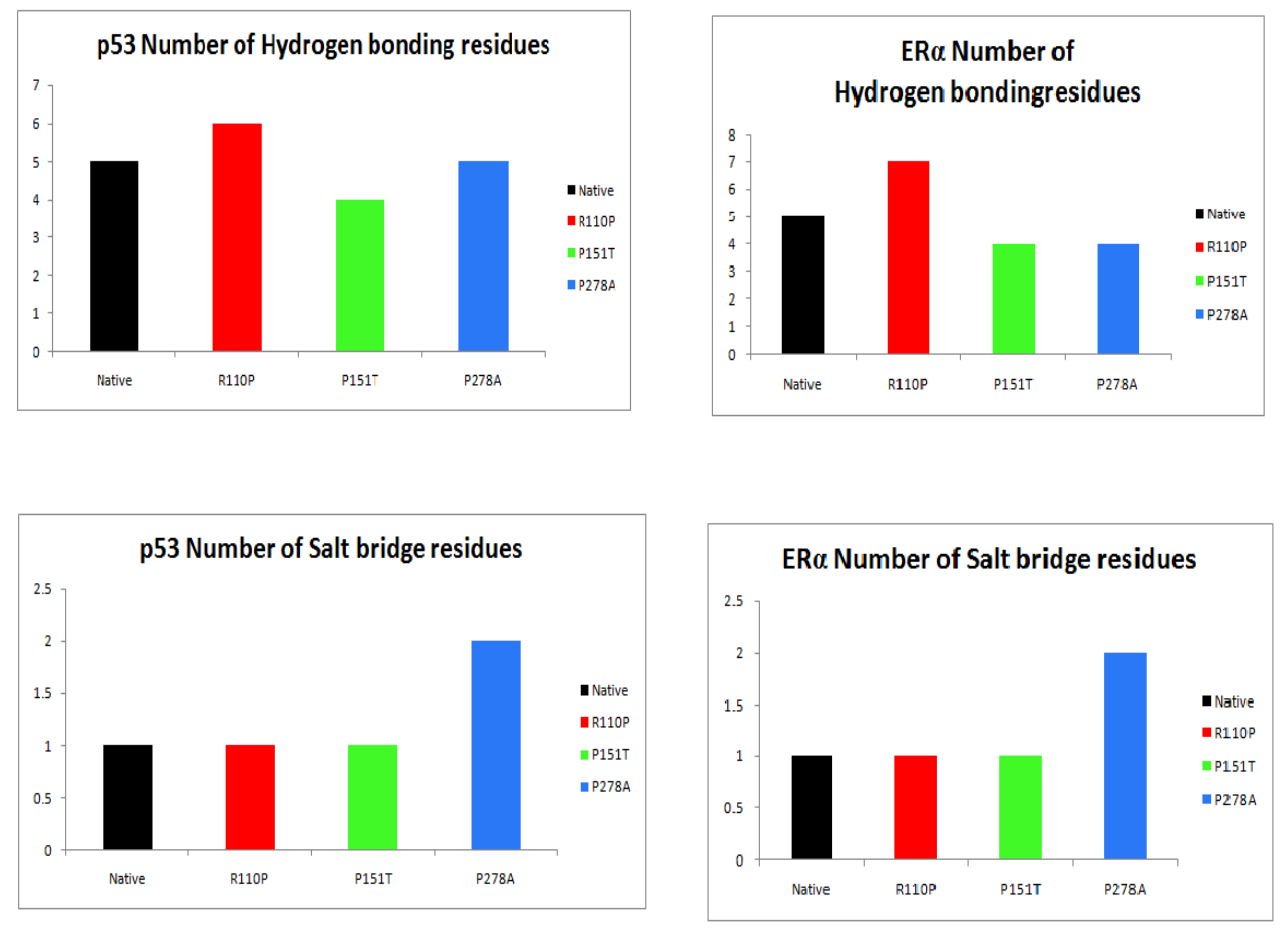

Figure 4. Analysis of the number of hydrogen bonding and salt bridge residues in p53-ER $\alpha$ complexes. Black: native or WT, Red: R110P, Green: P151T, Blue: P278A.
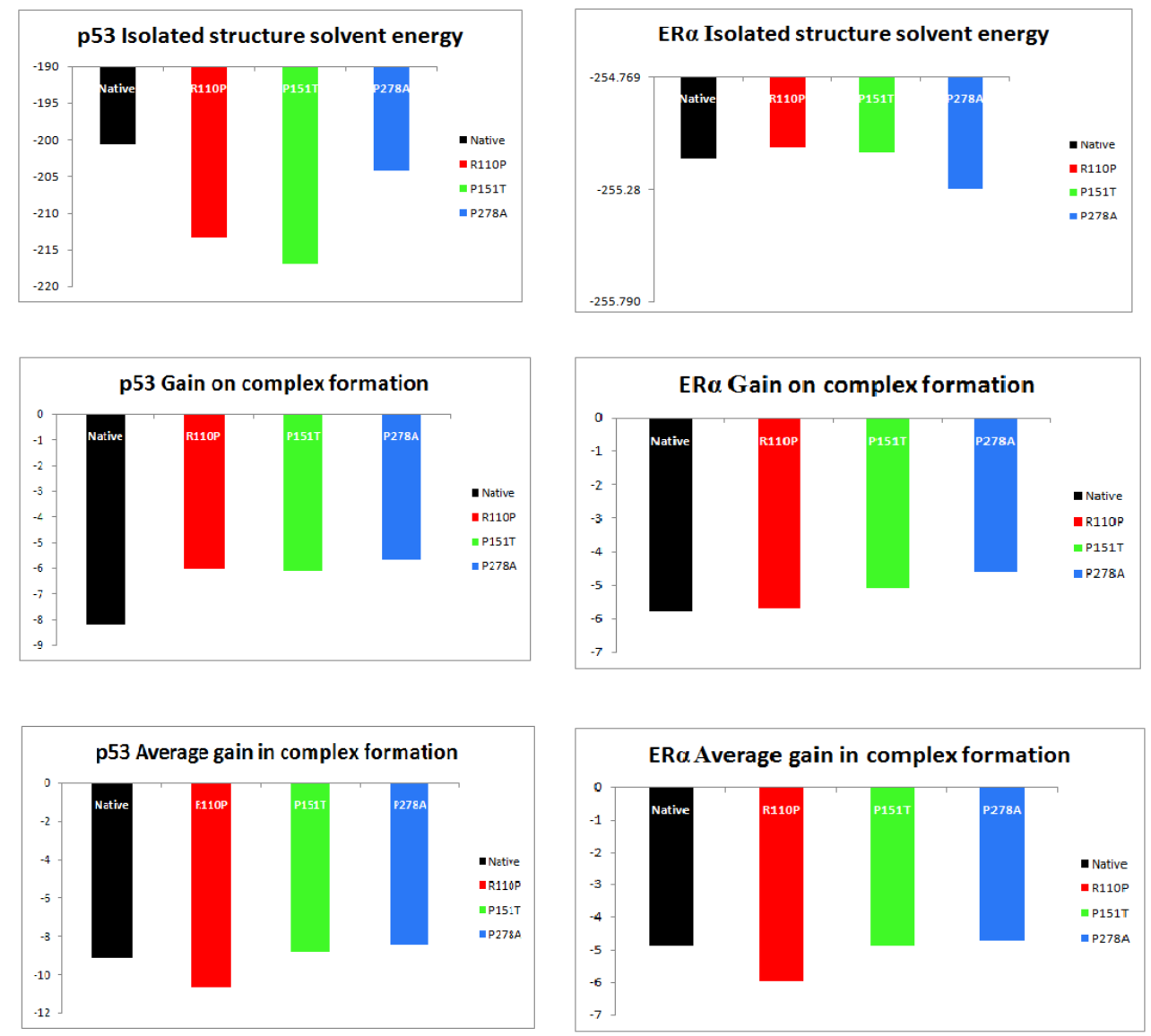

Figure 5. Analysis of the isolated solvent energy and gain in complex formation in p53-ER $\alpha$ complexes. Black: native or WT, Red: R110P, Green: P151T, Blue: P278A. 


\subsection{Artificial Neural Network Analysis}

Results from the protein-protein docking analysis showed that all three mutants are known to show an impact on the interaction between p53 and ER $\alpha$. We used this dataset for building an artificial neural network. These neural networks are nothing but, simple elements operating in parallel. The network function is determined largely by the connections between elements. We used a multilayer perceptron function for building the neural network. Multilayer perceptron involves building the class prediction function using backpropagation for minimizing the errors during learning by adjusting the weights of the connections between the network's nodes [21]. The general architecture of a multilayer perceptron involves an input layer, a hidden layer, and an output layer. The respective attributes and dataset pre-analysis used for building the neural network for the p53-ER $\alpha$ interaction is given in Tables 2 and 3 given below. Results from the neural network analysis showed that pre-analysis datasets given in the Table 3 showed 100 percent correct instances compared to the including all the attributes that are given in Table 2 indicating that these structural features are important for predicting the impact of these three mutants on the p53-ER $\alpha$ interaction. The respective artificial neural network architecture and its summary information are given in Figure $6 \mathrm{a}, \mathrm{b}$ given below.

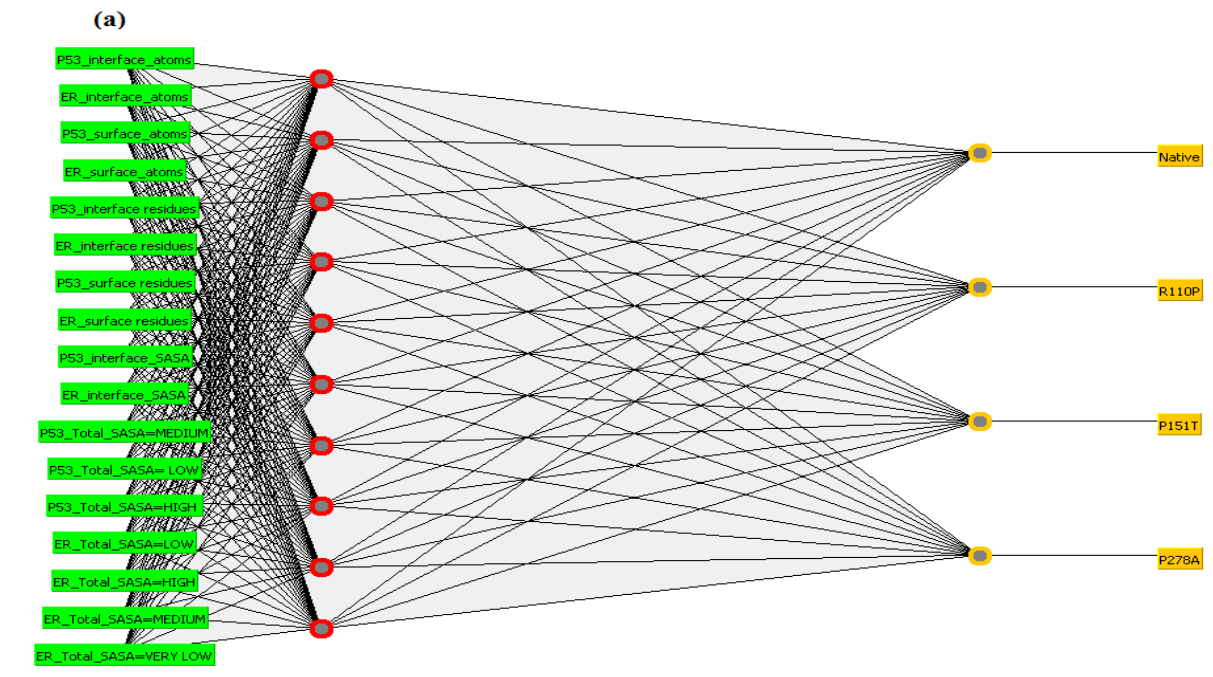

(b)

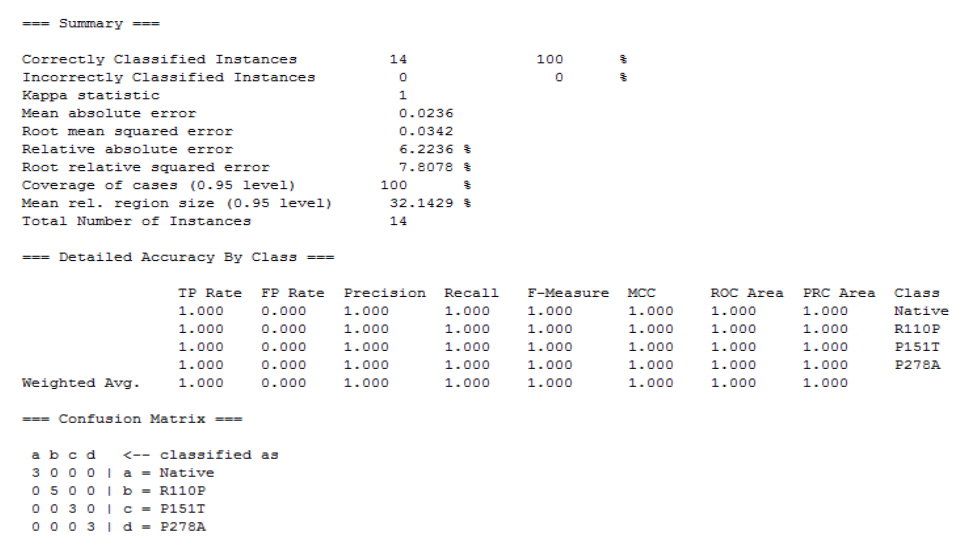

Figure 6. Neural network architecture for identification of the impact of mutants on p53-ER $\alpha$ interaction (a) Represents the neural network architecture for identification of the impact of mutants on p53-ER $\alpha$ interaction. The input layer is the pre-analysis dataset given in the Table 3 and the output layer has four output nodes with native at the left and remaining three nodes for the three mutants R110P, P151T, P278A (b) Represents the summary information of the neural network. 
Table 2. Attributes used for building the neural network for p53-ER $\alpha$ interaction.

\begin{tabular}{|c|c|c|}
\hline Attribute & Variable Type & Value Range \\
\hline Interface atoms (p53) & Numerical (continuous) & $(74,179)$ \\
\hline Interface atoms ${ }^{(E R)}$ & Numerical (continuous) & $(75,173)$ \\
\hline Surface atoms (p53) & Numerical (continuous) & $(1933,1999)$ \\
\hline Surface atoms ${ }^{(E R)}$ & Numerical (continuous) & $(1154,1173)$ \\
\hline Interface residues $(\mathrm{p} 53)$ & Numerical (continuous) & $(16,53)$ \\
\hline Interface residues $(\mathrm{ER})$ & Numerical (continuous) & $(20,44)$ \\
\hline Surface residues $(\mathrm{p} 53)$ & Numerical (continuous) & $(365,374)$ \\
\hline Surface residues $(\mathrm{ER})$ & Numerical (continuous) & $(220,224)$ \\
\hline Interface SASA ${ }^{(p 53)}$ & Numerical (continuous) & $(693.5,1575.2)$ \\
\hline Interface SASA ${ }^{(E R)}$ & Numerical (continuous) & $(694.2,1521.7)$ \\
\hline Total SASA (p53) & Numerical (continuous) & $(23,820.5,24,850.6)$ \\
\hline Total SASA ${ }^{\text {(ER) }}$ & Numerical (continuous) & $(12,983.1,13,016.6)$ \\
\hline Isolated structure Solvent energy (p53) & Numerical (continuous) & $(-216.9,-200.6)$ \\
\hline Isolated structure Solvent energy (ER) & Numerical (continuous) & $(-255.9,254.6)$ \\
\hline Gain on Complex formation (p53) & Numerical (continuous) & $(-10.2,-2.0)$ \\
\hline Gain on Complex formation (ER) & Numerical (continuous) & $(-10.2,0.1)$ \\
\hline Average gain in Complex formation (p53) & Numerical (continuous) & $(-13.7,-5.9)$ \\
\hline Average gain in Complex formation ${ }^{(E R)}$ & Numerical (continuous) & $(-7.6,-3.3)$ \\
\hline Number of Hydrogen bonding residues $(\mathrm{p} 53)$ & Numerical (continuous) & $(0,13)$ \\
\hline Number of Hydrogen bonding residues (ER) & Numerical (continuous) & $(0,12)$ \\
\hline Number of Salt bridge residues (p53) & Numerical (continuous) & $(0,5)$ \\
\hline Number of Salt bridge residues (ER) & Numerical (continuous) & $(0,5)$ \\
\hline Complex & Categorical (quaternary) & (Native, R110P, P151T, P278A) \\
\hline
\end{tabular}

(p53) represents tumor suppressor p53; (ER) represents ER $\alpha$ attribute combinations.

Table 3. Dataset pre-analysis used for building the neural network for p53-ER $\alpha$ interaction.

\begin{tabular}{|c|c|c|}
\hline Attribute & Sub Groups \& Ranges & Value Range \\
\hline Total SASA (p53) & $\begin{array}{c}(\text { Very Low })=23,820.5 \\
(\text { Low })=<24,335.55 \\
(\text { Medium })=\geq 24,335.55 \\
(\text { High })=24,850.6\end{array}$ & $(23,820.5,24,850.6)$ \\
\hline Total SASA (ER) & $\begin{array}{c}(\text { Very Low })=12,983.1 \\
(\text { Low })=<12,999.85 \\
(\text { Medium })=\geq 12,999.85 \\
(\text { High })=13,016.6\end{array}$ & $(12,983.1,13,016.6)$ \\
\hline Average gain in Complex formation (p53) & $\begin{array}{c}(\text { Very Low })=-13.7 \\
(\text { Low })=-9.8 \\
(\text { Medium })=\geq-9.8 \\
(\text { High })=-5.9\end{array}$ & $(-13.7,-5.9)$ \\
\hline Average gain in Complex formation (ER) & $\begin{array}{c}(\text { Very Low })=-7.6 \\
(\text { Low })=<-5.45 \\
(\text { Medium })=\geq-5.45 \\
(\text { High })=-3.3\end{array}$ & $(-7.6,-3.3)$ \\
\hline Number of Hydrogen bonding residues $(\mathrm{p} 53)$ & $\begin{array}{c}(\text { None })=0 \\
(\text { Low })=<6 \\
(\text { Medium })=\geq 6 \\
(\text { High })=13\end{array}$ & $(0,13)$ \\
\hline
\end{tabular}


Table 3. Cont.

\begin{tabular}{|c|c|c|}
\hline Attribute & Sub Groups \& Ranges & Value Range \\
\hline Number of Hydrogen bonding residues (ER) & $\begin{array}{c}(\text { None })=0 \\
(\text { Low })=<6 \\
(\text { Medium })=\geq 6 \\
(\text { High })=12\end{array}$ & $(0,12)$ \\
\hline Number of Salt bridge residues $(\mathrm{p} 53)$ & $\begin{array}{c}(\text { None })=0 \\
(\text { Low })=<2 \\
(\text { Medium })=\geq 2 \\
(\text { High })=5\end{array}$ & $(0,5)$ \\
\hline Number of Salt bridge residues (ER) & $\begin{array}{c}(\text { None })=0 \\
(\text { Low })=<2 \\
(\text { Medium })=\geq 2 \\
(\text { High })=5\end{array}$ & $(0,5)$ \\
\hline
\end{tabular}

(p53) represents tumor suppressor p53; (ER) represents ER $\alpha$ attribute combinations.

\section{Materials and Methods}

\subsection{Full-Length Structure of $p 53$}

To investigate the mechanism of the impact of deleterious mutants R110P, P151T and P278A on the interaction with estrogen receptor alpha, we used a protein-protein interaction study. The size of the p53 tetramer is about $43 \mathrm{kDa}$ for the monomer and less than $200 \mathrm{kDa}$ for the tetramer, making it one of the smallest proteins ever studied by electron microscopy single particle reconstruction. Two different EM studies obtained different results. To the best of our knowledge the complete structure of the p53 protein is not available [22]. With the knowledge of the atomic structure of the individual domains, we have defined the full structure of p53 using homology modeling. Since we were analyzing the impact of deleterious mutations predicted in TP53 on the p53-ER $\alpha$ interaction, we used our modelled structure instead of the PDB structure 2ocj (which contains only the DNA binding domain) used in our previous study [20]. The complete protein sequence of p53 was retrieved from Universal Protein Knowledgebase [23] (UniParc ID: P04637) and a BLAST search was done to predict the templates for individual domains of p53. Quality of the built models was assessed using PROCHECK available at Structural Analysis and Verification Server (SAVES: (http://nihserver.mbi.ucla.edu/SAVES/). The built model was subjected to minimization using NOMAD-Ref web server available at http://lorentz.immstr.pasteur.fr/nomad-ref.php with default settings [24].

\subsection{Structure of ER $\alpha$ and Interaction of $p 53-E R \alpha$}

Since the activation function-2 (AF-2) domain of ER $\alpha$ is necessary for interaction with p53 [15], three dimensional coordinates of the crystal structure of Human estrogen receptor alpha ligand-binding domain in complex with compound 11F (PDB code: 2IOG) with a high-resolution of $1.60 \AA$ containing residues 306 to 554 (AF-2 domain) downloaded from the Protein Data Bank [25] was used for the p53-ER $\alpha$ interaction analysis. Modelled native and mutant p53 interactions with ER $\alpha$ were studied by subjecting them to protein-protein docking using ZDOCK 3.0.2: an automated server available at http: //zdock.umassmed.edu/ [26]. Since residues in the regulatory domain of p53 are important for interaction with $\mathrm{ER} \alpha$, residues 363 to 393 were selected as binding site residues for ZDOCK protein-protein docking. All ten docking complexes were used for our analysis. Mutants (MTs) R110P, P151T and P278A were created by replacing the wild-type (WT) protein residue with its polymorphic residue using PyMOL [27] and minimized using NOMAD-Ref server. Properties of the native p53-ER $\alpha$ and mutant p53-ER $\alpha$ complexes were analyzed using Protein Interfaces, Surfaces and Assemblies service (PISA), available at European Bioinformatics Institute (http://www.ebi.ac.uk/msd-srv/prot_int/cgi-bin/piserver) [28]. 


\subsection{Machine Learning Approach}

Machine learning is a process of identifying the structure in a given data, in an automated or semi-automated way through a process called data mining. These machine learning approaches have the ability to generate models for prediction by extensively searching through the model and parameter space [29]. Previously, several studies have been done on protein-protein interactions using machine learning approaches [30-32]. Therefore, a diverse predictive model from machine learning or data mining has been employed here to perform predictions on the effect of these three mutations on the p53-ER $\alpha$ interaction. List of attributes mentioned in Table 2 given below was used for modeling using Weka 3.7.11. [33].

\section{Discussion}

Breast cancer is the most common and frequent cancer type for women around the world. Based on its complexity, heterogenicity and histological features, it has been classified into hormone-receptor-positive, human epidermal growth factor receptor-2 overexpressing (HER2+) and triple-negative breast cancer (TNBC) [34]. There are several genetic and nongenetic factors that confirm risk to breast cancer. In general, breast cancer susceptibility genes have been classified into high, moderate and low penetrance genes; each of them is interacting with several genes and environmental factors [35]. High penetrance genes include BRCA1, BRCA2, PTEN, TP53, CDH1 and STK11 whereas moderate penetrance genes include CHEK2, BRIP1, ATM and PALB2 [36].

Among the high penetrance genes, p53 has a significant role in the malignancy of breast cancer with it mutations were more frequently observed in $30 \%$ of the breast carcinomas of which $26 \%$ are in luminal tumors (17\% of luminal A, $41 \%$ of luminal B), $50 \%$ are in HER 2 amplified tumors, $69 \%$ are in molecular apocrine breast carcinomas and $88 \%$ are in basal-like carcinomas [37]. In our previous study, we have screened the total number of non-synonymous coding single nucleotide polymorphisms (SNPs) in TP53 gene and precited three deleterious coding non-synonymous SNPs rs11540654, rs17849781 and rs28934874 coding for mutations R110P, P278A, P151T in TP53 with a phenotype in breast tumors using computational tools SIFT, Polyphen-2 and MutDB. Our results showed that these three mutations R110P, P151T and P278A have major consequences on the native p53 DNA-binding core domain RMSD, Rg, SASA, NH bond and number density in the presence and absence of $\mathrm{Zn}^{2+}$ ion [20]. Previous reports showed that R110P confers a loss of Tp53 protein function by decreased DNA binding and transactivation of Tp53 targets, and Caspase 3/7 activity in culture and an increased aggregation with Tp63, and Tp73 [38,39]. P278A mutation on TP53 is known to show a loss of Tp53 transcription activity and a decrease in DNA binding and a failure to induce apoptosis in cell culture [39]. P151T on the other hand known to be found in the patients with early onset breast cancer $[40,41]$.

In the present study, we aimed to investigate the impact of these three p53 mutations (R110P, P151T, P278A) on its interacting partners. Previous studies showed that p53 is known to interact with several other receptors thereby regulating a wide array of cellular processes leading to essential protection against cancer development [42-44]. Among the several interactions, one of the key interacting partner for p53 is ER $\alpha$ which directly bind to p53 thereby opposing p53-mediated apoptosis in breast cancer cells [15,45]. To this end, we have analyzed the impact of these three p53 mutations (R110P, P151T, P278A) on the estrogen receptor alpha-p53 interaction. The complete three-dimensional structure of p53 is still unavailable to date due to its intricate complexity and a comparatively little progress has been made through the years [46]. Therefore, in the present study, we have constructed the three-dimensional structure of p53 using a computational molecular modelling approach. The molecular modelling approach has been successful in several previous studies studying cancer mutations [47-49]. The complete sequence of human p53 was downloaded from the Universal Protein Knowledgebase database (UniParc ID: P04637) and searched for possible templates in the PDB structure database [50] using the BLAST search engine. Our results showed that four templates (Table 1) have a higher percentage of similarity with the $\mathrm{p} 53$ protein sequence. The built homology model was 
validated for a quality assessment using PROCHEK. Validated model was energy minimized and the mutants R110P, P151T, P278A were created by replacing the respective wild type p53 protein residues with its polymorphic residue using PyMOL software [27].

Human ER $\alpha$ is a 595 amino acids protein with an approximate molecular weight of 66-70 kDa [11]. Starting from NH2- to COO-terminus, $\mathrm{ER} \alpha$ contains a typical structure of the nuclear receptor family with a highly variable $\mathrm{N}$-terminal region (A/B domain), a highly conserved DNA-binding domain (C), a hinge domain (D), a ligand-binding domain (E) and a C-terminal domain (F). ER $\alpha$ is a ligand-inducible transcription factor which upon hormone binding, gets activated and regulates the transcription of target genes. Ligand-dependent and independent activation of ER $\alpha$ is done by the N-terminal A/B domain region (transactivation function-1 (AF-1)) whereas dimerization and binding to the coactivators and corepressors are done by the ligand-binding domain (transactivation function-2 (AF-2)) [51]. ER $\alpha$ is known to be expressed in approximately $70 \%$ of all the human breast cancers and a high level of ER $\alpha$ is associated with tumor differentiation thereby showing strong clinical evidence supporting its role in breast cancer [52,53]. ER $\alpha$ isoform primarily contributes to estrogen-induced growth stimulatory effects in breast cancer [54]. Point mutations in ER $\alpha$ may lead to hypersensitive estrogen breast hyperplasia [55] and several splice variants in ER $\alpha$ are known to be found in various tumor types of breast cancer. Among them, a variant in exon $\Delta 3$ of ER $\alpha$ (missing part of the central DNA binding domain) is known to function as a dominant-negative receptor, able to suppress estrogen-induced transcriptional activity [56]. PvuII polymorphism in the ER $\alpha$, or another mutation in linkage disequilibrium with PvuII, in combination with high estradiol levels, is known to increase the breast cancer risk in postmenopausal women [57].

ER $\alpha$ plays an important role in the malignant progression of breast cancer. Two hypotheses were proposed to explain ER $\alpha$ association with breast cancer: (i) products of estrogen metabolism are genotoxic causing an increased risk of direct DNA damage; (ii) estrogen-induced activity of estrogen receptors stimulates proliferation leading to increased risk of DNA mutations due to high rates of DNA replication. Tamoxifen inhibits the ER $\alpha$ transcriptional activity in mammary cells and effectively reduces the risk of recurrence of invasive or in situ ER $\alpha$ positive breast cancer [52]. It is known to fail for treating breast cancer due to (i) the existence of ER $\beta$ (ii) an imbalance between estrogen biosynthesis and catabolism (iii) an altered bioavailability iv) altered cellular trafficking of ER (v) nongenomic effects of ER (vi) transcriptional dysregulation of ER target genes [58].

Among the different domains of $\mathrm{ER} \alpha$, the activation function-2 (AF-2) domain is known to be necessary for binding to the C-terminal regulatory domain of p53 [15]. The schematic structure of the respective interactions of $\mathrm{ER} \alpha$ with $\mathrm{p} 53$ is shown in Figure 1. In general, protein-protein interfaces i.e., abbreviated as protein interfaces or interfaces are the regions where two proteins may show direct physical contact [59]. Since these interfaces are directly involved in protein-protein interactions the atoms and the residues at these interfaces play a prominent role in elucidating a protein interaction mechanism. Results from the protein-protein docking between p53 and ER $\alpha$ showed that interface atoms, interface residues, and interface SASA was increased in both p53 and ER $\alpha$ for R110P compared to the native complexes demonstrating that R110P mutation has more influence on the p53-ER $\alpha$ interaction interface compared to the other two mutants P151T and P278A.

Understanding the folding mechanisms of a protein involves the study of various structural parameters of proteins such as secondary structures, side chain interactions, H-bonds and surface residues. Generally, protein active sites are often situated at the surface of the protein, greater understanding into residue accessibility would be significant in understanding and predicting the structure/function relationships [60]. Results from our study demonstrated that the mutants $\mathrm{P} 151 \mathrm{~T}$ and P278A show a large deviation from the native p53-ER $\alpha$ complex in the surface atoms and surface residues compared to R110P. Overall, our results demonstrated that all three mutants showed a large deviation in the total solvent accessible surface area (Figure 3). Further, another parameter to understand and analyze the interactions across protein-protein interfaces is hydrogen bonds and of the salt bridges [61]. Results from the analysis of number of hydrogen bonding residues and the 
number of salt bridges showed that is an increase in the number of hydrogen bonding residues in $\mathrm{R} 110 \mathrm{P}$ whereas there is an increase in number salt bridge forming residues in the mutant P278A (Figure 4) indicating there is a change in global conformation induced by these residues at the p53-ER $\alpha$ interface. Overall, our results demonstrate that all these three mutations have an impact on the p53-ER $\alpha$ interaction.

Machine learning is an emerging scientific discipline focusing on intersecting statistics in relation to data and computer science with its emphasis on implementing efficient computing algorithms [62]. Previous studies showed that machine learning models have been successful in breast cancer studies [63-65]. In the present study, to check whether the structural features we have analyzed are important for predicting the impact of these three mutants on the p53-ER $\alpha$ interaction, we used Weka a data mining toolkit that implements the machine learning algorithms [66]. We have used the data generated from the protein-protein docking results of the native, R110P, P151T and P278A p53-ER $\alpha$ complexes to building an artificial neural network using multilayer perceptron function of Weka software (Figure 6) (Tables 2 and 3). Overall our results demonstrate that the structural features of interface atoms, surface atoms, interface residues, surface residues, interface SASA, total SASA, isolated structure Solvent energy, gain on complex formation, average gain in complex formation, number of hydrogen bonding residues and number of salt bridge residues are significant for predicting the impact of the mutations R110P, P278A and P151T induced by the deleterious breast cancer SNPs rs11540654, rs17849781 and rs28934874 predicted in our previous study [20] on the p53-ER $\alpha$ interaction.

\section{Conclusions}

Almost 70\% of human breast cancers are ER-positive and hormone-dependent. Hormonal therapy to treat ER-positive breast cancer is one of the most extensively described uses of personalized medicine and has been studied for over a century. Results from the present study conclusively show that the three mutants R110P, P151T and P278A that are predicted to be deleterious on the DNA binding domain of p53 have an impact on the interaction with the ligand binding domain of human estrogen receptor alpha. The parameters interface and surface residues, interface and total SASA contribute to the overall impact of these three mutants on the p53-ER $\alpha$ interaction. Overall, results from our study can be useful as a tool to predict the impact of mutations in the ER-positive breast cancer patients and can be useful for decision making.

Author Contributions: Conceptualization, K.N.C. and S.Y.; Data curation, K.N.C.; Formal analysis, K.N.C.; Funding acquisition, M.N., P.N. and S.Y.; Investigation, K.N.C.; Methodology, K.N.C.; Project administration, M.N., P.N. and S.Y.; Resources, M.N., P.N. and S.Y.; Software, K.N.C.; Supervision, M.N., P.N. and S.Y.; Validation, K.N.C.; Visualization, K.N.C.; Writing—original draft, K.N.C.; Writing—review \& editing, K.N.C., M.N., P.N. and S.Y.

Funding: The present study was supported by the ICMR, Human Resource Development for Health Research, New Delhi (F.No. V0.25011/542-HRD/2016-HR).

Conflicts of Interest: The authors declare no conflict of interest. The funders had no role in the design of the study; in the collection, analyses, or interpretation of data; in the writing of the manuscript, or in the decision to publish the results.

\section{References}

1. Hortobagyi, G.N.; de la Garza Salazar, J.; Pritchard, K.; Amadori, D.; Haidinger, R.; Hudis, C.A.; Khaled, H.; Liu, M.C.; Martin, M.; Namer, M.; et al. The global breast cancer burden: Variations in epidemiology and survival. Clin. Breast Cancer 2005, 6, 391-401. [CrossRef] [PubMed]

2. Porter, P. “Westernizing” women's risks? Breast cancer in lower-income countries. N. Engl. J. Med. 2008, 358, 213-216. [CrossRef] [PubMed]

3. Anderson, B.O.; Jakesz, R. Breast cancer issues in developing countries: An overview of the Breast Health Global Initiative. World J. Surg. 2008, 32, 2578-2585. [CrossRef] [PubMed]

4. Green, M.; Raina, V. Epidemiology, screening and diagnosis of breast cancer in the Asia-Pacific region: Current perspectives and important considerations. Asia-Pac. J. Clin. Oncol. 2008, 4, S5-S13. [CrossRef] 
5. Agarwal, G.; Ramakant, P. Breast Cancer Care in India: The Current Scenario and the Challenges for the Future. Breast Care 2008, 3, 21-27. [CrossRef] [PubMed]

6. Singletary, S.E. Rating the risk factors for breast cancer. Ann. Surg. 2003, 237, 474-482. [CrossRef] [PubMed]

7. Sanchez, A.M.; Flamini, M.I.; Baldacci, C.; Goglia, L.; Genazzani, A.R.; Simoncini, T. Estrogen receptor-alpha promotes breast cancer cell motility and invasion via focal adhesion kinase and N-WASP. Mol. Endocrinol. 2010, 24, 2114-2125. [CrossRef]

8. Yu, C.P.; Deeb, R.A.; Chu, K.H. Microbial degradation of steroidal estrogens. Chemosphere 2013, 91, 1225-1235. [CrossRef]

9. Minkin, M.J.; Maamari, R.; Reiter, S. Improved compliance and patient satisfaction with estradiol vaginal tablets in postmenopausal women previously treated with another local estrogen therapy. Int. J. Women's Health 2013, 5, 133-139. [CrossRef]

10. Platet, N.; Cathiard, A.M.; Gleizes, M.; Garcia, M. Estrogens and their receptors in breast cancer progression: A dual role in cancer proliferation and invasion. Crit. Rev. Oncol. Hematol. 2004, 51, 55-67. [CrossRef]

11. Pavao, M.; Traish, A.M. Estrogen receptor antibodies: Specificity and utility in detection, localization and analyses of estrogen receptor alpha and beta. Steroids 2001, 66, 1-16. [CrossRef]

12. Jiang, X. Harnessing the immune system for the treatment of breast cancer. J. Zhejiang Univ. Sci. B 2014, 15, 1-15. [CrossRef] [PubMed]

13. Bailey, S.T.; Shin, H.; Westerling, T.; Liu, X.S.; Brown, M. Estrogen receptor prevents p53-dependent apoptosis in breast cancer. Proc. Natl. Acad. Sci. USA 2012, 109, 18060-18065. [CrossRef] [PubMed]

14. Ross-Innes, C.S.; Stark, R.; Holmes, K.A.; Schmidt, D.; Spyrou, C.; Russell, R.; Massie, C.E.; Vowler, S.L.; Eldridge, M.; Carroll, J.S. Cooperative interaction between retinoic acid receptor-alpha and estrogen receptor in breast cancer. Genes Dev. 2010, 24, 171-182. [CrossRef] [PubMed]

15. Liu, W.; Konduri, S.D.; Bansal, S.; Nayak, B.K.; Rajasekaran, S.A.; Karuppayil, S.M.; Rajasekaran, A.K.; Das, G.M. Estrogen receptor-alpha binds p53 tumor suppressor protein directly and represses its function. J. Biol. Chem. 2006, 281, 9837-9840. [CrossRef] [PubMed]

16. Berger, C.E.; Qian, Y.; Liu, G.; Chen, H.; Chen, X. p53, a target of estrogen receptor (ER) alpha, modulates DNA damage-induced growth suppression in ER-positive breast cancer cells. J. Biol. Chem. 2012, 287, 30117-30127. [CrossRef] [PubMed]

17. Konduri, S.D.; Medisetty, R.; Liu, W.; Kaipparettu, B.A.; Srivastava, P.; Brauch, H.; Fritz, P.; Swetzig, W.M.; Gardner, A.E.; Khan, S.A.; et al. Mechanisms of estrogen receptor antagonism toward p53 and its implications in breast cancer therapeutic response and stem cell regulation. Proc. Natl. Acad. Sci. USA 2010, 107, 15081-15086. [CrossRef] [PubMed]

18. Liu, W.; Ip, M.M.; Podgorsak, M.B.; Das, G.M. Disruption of estrogen receptor alpha-p53 interaction in breast tumors: A novel mechanism underlying the anti-tumor effect of radiation therapy. Breast Cancer Res. Treat. 2009, 115, 43-50. [CrossRef]

19. Ratanaphan, A. A DNA Repair BRCA1 Estrogen Receptor and Targeted Therapy in Breast Cancer. Int. J. Mol. Sci. 2012, 13, 14898-14916. [CrossRef]

20. Chitrala, K.N.; Yeguvapalli, S. Computational screening and molecular dynamic simulation of breast cancer associated deleterious non-synonymous single nucleotide polymorphisms in TP53 gene. PLoS ONE 2014, 9, e104242. [CrossRef]

21. Rumelhart, D.E.; Hinton, G.E.; Williams, R.J. Learning representations by back-propagating errors. Nature 1986, 323, 533-536. [CrossRef]

22. Viadiu, H. Molecular architecture of tumor suppressor p53. Curr. Top. Med. Chem. 2008, 8, 1327-1334. [CrossRef]

23. Apweiler, R.; Bairoch, A.; Wu, C.H.; Barker, W.C.; Boeckmann, B.; Ferro, S.; Gasteiger, E.; Huang, H.; Lopez, R.; Magrane, M.; et al. UniProt: The Universal Protein knowledgebase. Nucleic Acids Res. 2004, 32, D115-D119. [CrossRef] [PubMed]

24. Lindahl, E.; Azuara, C.; Koehl, P.; Delarue, M. NOMAD-Ref: Visualization, deformation and refinement of macromolecular structures based on all-atom normal mode analysis. Nucleic Acids Res. 2006, 34, W52-W56. [CrossRef]

25. Dykstra, K.D.; Guo, L.; Birzin, E.T.; Chan, W.; Yang, Y.T.; Hayes, E.C.; DaSilva, C.A.; Pai, L.Y.; Mosley, R.T.; Kraker, B.; et al. Estrogen receptor ligands. Part 16: 2-Aryl indoles as highly subtype selective ligands for ERalpha. Bioorg. Med. Chem. Lett. 2007, 17, 2322-2328. [CrossRef] [PubMed] 
26. Chen, R.; Li, L.; Weng, Z. ZDOCK: An initial-stage protein-docking algorithm. Proteins 2003, 52, 80-87. [CrossRef]

27. PyMol, version 0.99; DeLano Scientific: San Carlos, CA, USA, 2006.

28. Krissinel, E.; Henrick, K. Inference of macromolecular assemblies from crystalline state. J. Mol. Biol. 2007, 372, 774-797. [CrossRef]

29. Mani, S.; Chen, Y.; Li, X.; Arlinghaus, L.; Chakravarthy, A.B.; Abramson, V.; Bhave, S.R.; Levy, M.A.; Xu, H.; Yankeelov, T.E. Machine learning for predicting the response of breast cancer to neoadjuvant chemotherapy. J. Am. Med. Inform. Assoc. 2013, 20, 688-695. [CrossRef]

30. Kamada, M.; Sakuma, Y.; Hayashida, M.; Akutsu, T. Prediction of protein-protein interaction strength using domain features with supervised regression. Sci. World J. 2014, 2014, 240673. [CrossRef] [PubMed]

31. van Vugt, M.K. Ballet as a movement-based contemplative practice? Implications for neuroscientific studies. Front. Hum. Neurosci. 2014, 8, 513. [CrossRef] [PubMed]

32. Chatterjee, P.; Basu, S.; Kundu, M.; Nasipuri, M.; Plewczynski, D. PPI_SVM: Prediction of protein-protein interactions using machine learning, domain-domain affinities and frequency tables. Cell. Mol. Biol. Lett. 2011, 16, 264-278. [CrossRef] [PubMed]

33. Hall, M.; Frank, E.; Holmes, G.; Pfahringer, B.; Reutemann, P.; Witten, I.H. The WEKA Data Mining Software: An Update. Sigkdd Explor. 2009, 11. [CrossRef]

34. Nagini, S. Breast Cancer: Current Molecular Therapeutic Targets and New Players. Anti-Cancer Agents Med. Chem. 2017, 17, 152-163. [CrossRef]

35. Mahdavi, M.; Nassiri, M.; Kooshyar, M.M.; Vakili-Azghandi, M.; Avan, A.; Sandry, R.; Pillai, S.; Lam, A.K.; Gopalan, V. Hereditary breast cancer; Genetic penetrance and current status with BRCA. J. Cell. Physiol. 2018. [CrossRef] [PubMed]

36. Shiovitz, S.; Korde, L.A. Genetics of breast cancer: A topic in evolution. Ann. Oncol. 2015, 26, 1291-1299. [CrossRef] [PubMed]

37. Bertheau, P.; Lehmann-Che, J.; Varna, M.; Dumay, A.; Poirot, B.; Porcher, R.; Turpin, E.; Plassa, L.F.; de Roquancourt, A.; Bourstyn, E.; et al. p53 in breast cancer subtypes and new insights into response to chemotherapy. Breast 2013, 22, S27-S29. [CrossRef] [PubMed]

38. Xu, J.; Reumers, J.; Couceiro, J.R.; De Smet, F.; Gallardo, R.; Rudyak, S.; Cornelis, A.; Rozenski, J.; Zwolinska, A.; Marine, J.C.; et al. Gain of function of mutant p53 by coaggregation with multiple tumor suppressors. Nat. Chem. Biol. 2011, 7, 285-295. [CrossRef]

39. Wang, B.; Niu, D.; Lam, T.H.; Xiao, Z.; Ren, E.C. Mapping the p53 transcriptome universe using p53 natural polymorphs. Cell Death Differ. 2014, 21, 521-532. [CrossRef]

40. Cao, A.Y.; Huang, J.; Hu, Z.; Li, W.F.; Ma, Z.L.; Tang, L.L.; Zhang, B.; Su, F.X.; Zhou, J.; Di, G.H.; et al. Mutation analysis of BRIP1/BACH1 in BRCA1/BRCA2 negative Chinese women with early onset breast cancer or affected relatives. Breast Cancer Res. Treat. 2009, 115, 51-55. [CrossRef]

41. Maxwell, K.N.; Wubbenhorst, B.; D'Andrea, K.; Garman, B.; Long, J.M.; Powers, J.; Rathbun, K.; Stopfer, J.E.; Zhu, J.; Bradbury, A.R.; et al. Prevalence of mutations in a panel of breast cancer susceptibility genes in BRCA1/2-negative patients with early-onset breast cancer. Genet. Med. 2015, 17, 630-638. [CrossRef]

42. Kastenhuber, E.R.; Lowe, S.W. Putting p53 in Context. Cell 2017, 170, 1062-1078. [CrossRef]

43. Fernandez-Fernandez, M.R.; Sot, B. The relevance of protein-protein interactions for p53 function: The CPE contribution. Protein Eng. Des. Sel. 2011, 24, 41-51. [CrossRef] [PubMed]

44. Brady, C.A.; Attardi, L.D. p53 at a glance. J. Cell Sci. 2010, 123, 2527-2532. [CrossRef]

45. Sayeed, A.; Konduri, S.D.; Liu, W.; Bansal, S.; Li, F.; Das, G.M. Estrogen receptor alpha inhibits p53-mediated transcriptional repression: Implications for the regulation of apoptosis. Cancer Res. 2007, 67, 7746-7755. [CrossRef] [PubMed]

46. Joerger, A.C.; Fersht, A.R. The tumor suppressor p53: From structures to drug discovery. Cold Spring Harb. Perspect. Biol. 2010, 2, a000919. [CrossRef] [PubMed]

47. Herzog, G.; Joerger, A.C.; Shmueli, M.D.; Fersht, A.R.; Gazit, E.; Segal, D. Evaluating Drosophila p53 as a model system for studying cancer mutations. J. Biol. Chem. 2012, 287, 44330-44337. [CrossRef] [PubMed]

48. Pagano, B.; Jama, A.; Martinez, P.; Akanho, E.; Bui, T.T.; Drake, A.F.; Fraternali, F.; Nikolova, P.V. Structure and stability insights into tumour suppressor p53 evolutionary related proteins. PLoS ONE 2013, 8, e76014. [CrossRef] 
49. Hwang, L.A.; Phang, B.H.; Liew, O.W.; Iqbal, J.; Koh, X.H.; Koh, X.Y.; Othman, R.; Xue, Y.; Richards, A.M.; Lane, D.P.; et al. Monoclonal Antibodies against Specific p53 Hotspot Mutants as Potential Tools for Precision Medicine. Cell Rep. 2018, 22, 299-312. [CrossRef]

50. Burley, S.K.; Berman, H.M.; Kleywegt, G.J.; Markley, J.L.; Nakamura, H.; Velankar, S. Protein Data Bank (PDB): The Single Global Macromolecular Structure Archive. Methods Mol. Biol. 2017, 1607, 627-641.

51. Divekar, S.D.; Storchan, G.B.; Sperle, K.; Veselik, D.J.; Johnson, E.; Dakshanamurthy, S.; Lajiminmuhip, Y.N.; Nakles, R.E.; Huang, L.; Martin, M.B. The role of calcium in the activation of estrogen receptor-alpha. Cancer Res. 2011, 71, 1658-1668. [CrossRef]

52. Shanle, E.K.; Xu, W. Selectively targeting estrogen receptors for cancer treatment. Adv. Drug Deliv. Rev. 2010, 62, 1265-1276. [CrossRef] [PubMed]

53. Nykanen, M.; Kuopio, T. Protein and gene expression of estrogen receptor alpha and nuclear morphology of two breast cancer cell lines after different fixation methods. Exp. Mol. Pathol. 2010, 88, 265-271. [CrossRef] [PubMed]

54. Li, R.; He, P.; Cui, J.; Staufenbiel, M.; Harada, N.; Shen, Y. Brain endogenous estrogen levels determine responses to estrogen replacement therapy via regulation of BACE1 and NEP in female Alzheimer's transgenic mice. Mol. Neurobiol. 2013, 47, 857-867. [CrossRef] [PubMed]

55. Abbasi, S.; Rasouli, M.; Nouri, M.; Kalbasi, S. Association of estrogen receptor-alpha A908G (K303R) mutation with breast cancer risk. Int. J. Clin. Exp. Med. 2013, 6, 39-49. [PubMed]

56. Barone, I.; Iacopetta, D.; Covington, K.R.; Cui, Y.; Tsimelzon, A.; Beyer, A.; Ando, S.; Fuqua, S.A. Phosphorylation of the mutant K303R estrogen receptor alpha at serine 305 affects aromatase inhibitor sensitivity. Oncogene 2010, 29, 2404-2414. [CrossRef] [PubMed]

57. Onland-Moret, N.C.; van Gils, C.H.; Roest, M.; Grobbee, D.E.; Peeters, P.H. The estrogen receptor alpha gene and breast cancer risk (The Netherlands). Cancer Causes Control. 2005, 16, 1195-1202. [CrossRef] [PubMed]

58. Girault, I.; Bieche, I.; Lidereau, R. Role of estrogen receptor alpha transcriptional coregulators in tamoxifen resistance in breast cancer. Maturitas 2006, 54, 342-351. [CrossRef]

59. Gao, M.; Skolnick, J. Structural space of protein-protein interfaces is degenerate, close to complete, and highly connected. Proc. Natl. Acad. Sci. USA 2010, 107, 22517-22522. [CrossRef] [PubMed]

60. Lins, L.; Thomas, A.; Brasseur, R. Analysis of accessible surface of residues in proteins. Protein Sci. 2003, 12, 1406-1417. [CrossRef]

61. Xu, D.; Tsai, C.J.; Nussinov, R. Hydrogen bonds and salt bridges across protein-protein interfaces. Protein Eng. 1997, 10, 999-1012. [CrossRef]

62. Deo, R.C. Machine Learning in Medicine. Circulation 2015, 132, 1920-1930. [CrossRef] [PubMed]

63. Montazeri, M.; Montazeri, M.; Montazeri, M.; Beigzadeh, A. Machine learning models in breast cancer survival prediction. Technol. Health Care 2016, 24, 31-42. [CrossRef] [PubMed]

64. Nahid, A.A.; Kong, Y. Involvement of Machine Learning for Breast Cancer Image Classification: A Survey. Comput. Math. Methods Med. 2017, 2017, 3781951. [CrossRef] [PubMed]

65. Toprak, A. Extreme Learning Machine (ELM)-Based Classification of Benign and Malignant Cells in Breast Cancer. Med. Sci. Monit. 2018, 24, 6537-6543. [CrossRef] [PubMed]

66. Smith, T.C.; Frank, E. Introducing Machine Learning Concepts with WEKA. Methods Mol. Biol. 2016, 1418, 353-378.

(C) 2019 by the authors. Licensee MDPI, Basel, Switzerland. This article is an open access article distributed under the terms and conditions of the Creative Commons Attribution (CC BY) license (http://creativecommons.org/licenses/by/4.0/). 